\title{
Rodents Rely on Merkel Cells for Texture Discrimination Tasks
}

\author{
Stephen M. Maricich, ${ }^{1,2}$ Kristin M. Morrison, ${ }^{1}$ Erin L. Mathes, ${ }^{1}$ and Brittany M. Brewer ${ }^{1}$ \\ ${ }^{1}$ Department of Pediatrics and ${ }^{2}$ Departments of Dermatology, Neurosciences, and Otolaryngology, Case Western Reserve University, Cleveland, 0 hio 44106
}

The cutaneous somatosensory system contains multiple types of mechanoreceptors that detect different mechanical stimuli (Johnson, 2001). These stimuli, either alone or in combination, are ultimately interpreted by the brain as different aspects of the sense of touch. Psychophysical and electrophysiological experiments in humans and other mammals implicate one of these mechanoreceptors, the Merkel cell/neurite complex, in two-point discrimination and the detection of curvature, shape, and texture (Johnson and Lamb, 1981; Johnson et al., 2000; Johnson, 2001). However, whether Merkel cell/neurite complex function is required for the detection of these stimuli is unknown. We genetically engineered mice that lack Merkel cells (Maricich et al., 2009; Morrison et al., 2009) to directly test the hypothesis that Merkel cell/neurite complexes are necessary to perform these types of sensory discrimination tasks. We found that mice devoid of Merkel cells could not detect textured surfaces with their feet while other measures of motor and sensory function were unaffected. Interestingly, these mice retained the ability to discriminate both texture and shape using their whiskers, suggesting that other somatosensory afferents can functionally substitute for Merkel cell/neurite complexes in this sensory organ. These findings suggest that Merkel cell/neurite complexes are essential for texture discrimination tasks involving glabrous skin but not whiskers.

\section{Introduction}

The skin is innervated by an astonishing number of sensory afferent nerve fibers $\left[>600\right.$ nerve fibers $/ \mathrm{mm}^{2}$ in the human hand (Kelly et al., 2005)] that mediate all types of cutaneous sensations, including pain, temperature sense, and touch. The largest of these are the low-threshold mechanoreceptive $A \beta$-fibers involved in the sense of touch. Neurophysiological and psychophysical testing support assignment of differential functions to each $\mathrm{A} \beta$-fiber subclass. Based on responses to various cutaneous stimuli measured electrophysiologically in nerves that innervate the skin, Meissner corpuscles are hypothesized to be important for grip control, Pacinian corpuscles for representing tools as extensions of a limb, and Ruffini corpuscles for monitoring hand position and form (Johnson et al., 2000). Similarly, Merkel cell/neurite complexes, which respond to skin indentation (Iggo and Muir, 1969) at very high spatial resolution, are suggested to play a role in detection of curvature, edges, and shape. Importantly, all of these functional assignments are speculative to the extent that specific deletion of a subclass of cutaneous mechanoreceptors has not been possible.

Structurally, Merkel cell/neurite complexes are composed of slowly adapting type I (SAI) A $\beta$-nerve fibers and Merkel cells, a distinct cell population found primarily at the epidermal/dermal

Received Oct. 20, 2011; revised Dec. 21, 2011; accepted Jan. 14, 2012.

Author contributions: S.M.M. designed research;S.M.M., K.M.M., E.L.M., and B.M.B. performed research;S.M.M. analyzed data; S.M.M. wrote the paper.

This work was supported by the NIH Grants K08NS053419 and R01AR05114 to S.M.M. We thank Dr. Gemma Casadesus, Dr. Sharyl Fyffe-Maricich, and members of the Maricich laboratory for thoughtful discussions of the data and critical reading of the manuscript.

Correspondence should be addressed to Stephen M. Maricich at the above address. E-mail: smm18@case.edu. DOI:10.1523/JNEUROSCI.5307-11.2012

Copyright $\odot 2012$ the authors $\quad 0270-6474 / 12 / 323296-05 \$ 15.00 / 0$ border (Merkel, 1875). In mammals, these sensors are located in whisker follicles, the hard palate, specialized epithelial structures of the hairy skin called touch domes, and glabrous (hairless) skin surfaces such as the hand and foot (Halata et al., 2003). Genetic deletion of Merkel cells causes loss of SAI A $\beta$-fiber responses to mechanical stimulation of the skin, demonstrating that these cells are necessary for receptor function (Maricich et al., 2009).

An unresolved question in sensory biology is to what extent each afferent system contributes to the formation of somatosensory percepts such as roughness and shape. Correlative data from psychophysical experiments support the view that complex combinations of inputs are likely to be involved in forming somatosensory percepts. However, this question has been difficult to address experimentally because real-life stimuli often activate multiple receptor classes simultaneously. This is further complicated by the fact that cutaneous sensory end-organs can contain myelinated and unmyelinated afferents, suggesting that they may function as multimodal sensory receptors (Paré et al., 2001). In addition, how activation of non- $\mathrm{A} \beta$ afferents such as $\mathrm{C}$-fiber tactile afferents contributes to somatosensory percepts is unknown (Liu et al., 2007). Most importantly, how the loss of a single afferent population affects the ability to form tactile percepts and discriminate between them is unknown.

To address this question, we performed multiple behavioral tests that target the somatosensory system on mice lacking Merkel cells. Our data suggest that Merkel cells play a critical role in texture discrimination in the paws but not the whiskers.

\section{Materials and Methods}

Mice

Mice were maintained on a mixed genetic background in the Animal Resource Center at Case Western Reserve University in compliance with Institutional Animal Care and Use Committee guidelines. Atohl condi- 
tional knock-out $\left(A t o h 1^{C K O}\right)$ mice were generated by crossing $\mathrm{Krt14}{ }^{\mathrm{Cre}}$; Atoh1 $^{\text {LacZ }}$ (Ben-Arie et al., 1997; Dassule et al., 2000; Morrison et al., 2009) mice with Atoh $1^{\text {flox/flox }}$ (Shroyer et al., 2007) mice to generate four genotypes: $\mathrm{Krt1}^{+/+}$; Atoh $1^{+/ \text {flox }}, \mathrm{Krt1}^{\mathrm{Cre} /+}$; Atoh ${ }^{+/ \text {flox }}, \mathrm{Krt14}^{+/+}$; Atoh $1^{\text {LacZ/flox }}$, and $\mathrm{Krt14} 4^{\mathrm{Cre} /+} ;$ Atoh $1^{\text {LacZ/flox }}$. Only mice with $\mathrm{Krt14}{ }^{\mathrm{Cre}}$ and Atoh1 $1^{\text {LacZ }}$ alleles lacked Atoh1 expression in the Krt14 ${ }^{\text {Cre }}$ (Krt14; Atoh $\left.1^{\mathrm{CKO}}\right)$ distribution. Mice of the other three genotypes $\left(\mathrm{Krt}_{14^{+/+}}\right.$;

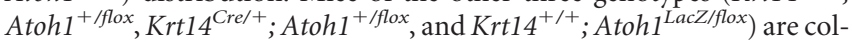
lectively referred to as "control" because they displayed no abnormal phenotypes and were indistinguishable based on the testing reported here.

\section{Behavioral testing}

Mice of both sexes aged 12-35 weeks were tested unless otherwise stated; Krt14; Atoh $1^{C K O}$ and control littermates were tested at the same age on any given task. Time of day for each test was constant across trials.

\section{Motor coordination and balance}

Rotarod test. Mice performed 16 trials ( 4 trials/d on 4 consecutive days) on a rotarod apparatus (Rotamex; Columbus Instruments) with a minimum rest interval of $20 \mathrm{~min}$ between trials. Trials lasted for a maximum of $5 \mathrm{~min}$; the rod accelerated linearly from 4 to $40 \mathrm{rpm}$ for the first $2.5 \mathrm{~min}$ and then stayed at $40 \mathrm{rpm}$ for $2.5 \mathrm{~min}$. Trials were terminated when an animal fell from the rod or rotated twice.

Dowel and wire hang tests. The dowel test involved placing mice in the center of a $7 \mathrm{~mm}$ diameter dowel suspended above a platform. Trials lasted for $2 \mathrm{~min}$ or until a fall, and the number of times that the mouse walked to one of the suspension posts (side touches) was recorded. The wire hang test was conducted identically except that a suspended wire was used.

\section{Texture discrimination in the paw}

This test was modified from a published mouse texture discrimination task (Wetzel et al., 2007). Test sessions were conducted in the dark under infrared illumination to remove visual cues and recorded with an infrared video camera. Half of the floor of a small Plexiglas box (length, $30 \mathrm{~cm}$; width, $15 \mathrm{~cm}$; height, $10 \mathrm{~cm}$ ) was covered with rough sandpaper (60 grit, coarse) and the other half with the smooth side of the same sandpaper; this ensured that odorant cues from the paper were identical throughout the box. Both pieces of sandpaper were changed and the box was cleaned with a diluted alcohol solution between animals. Mice were allowed to explore the arena for $30 \mathrm{~min}$, and the duration of time spent in each half of the arena was quantified by a computer-operated animal activity system (Ethovision XY; Noldus).

\section{Whisker tactile function}

Whisker brush test. This is a qualitative test of whisker sensation. Individual mice were placed in custom-made wire cages $(12 \times 8 \mathrm{~cm})$ for $4 \mathrm{~h}$ before testing. A plastic probe was then brushed caudal to rostral ( 3 trials/side) across the tips of the whiskers on one side of the snout to avoid visual cues; if the approach was sensed before contact, the mouse was allowed to settle and the test was restarted. Positive responses included turning to the side of stimulation, swatting at the probe with the forepaws, and grabbing the probe and biting it.

Modified gap test. The modified gap test was used to assess the ability of mice to detect differences in textures using only their whiskers (Carvell and Simons, 1990; Cybulska-Klosowicz and Kossut, 2001; von Heimendahl et al., 2007). Dietary intake was restricted to $2-3.5 \mathrm{~g} / \mathrm{d}$, and body weight maintained at $85-90 \%$ of the free-feeding weight. All animals were allowed access to water ad libitum. Individual mice were placed on a platform $\left(10 \mathrm{~cm}^{2}\right.$ Plexiglas $)$ and given the choice of crossing to one of two test platforms $\left(10 \mathrm{~cm}^{2}\right.$ Plexiglas) equidistant $(5 \mathrm{~cm})$ from the home platform. Each test platform had a $10 \times 1 \mathrm{~cm}$ removable surface on the side closest to the home platform that was textured (60-grit sand paper) or smooth (backside of the sand paper). A food reward (banana and sweet milk) was placed behind a wall on each of the test platforms to insure that odorant cues were identical; access to the reward was granted only to mice that chose the platform with the textured surface. Mice underwent 10 trials/d; each trial lasted 2 min or until a choice was made. Mice that made the incorrect choice were left on the platform for $1 \mathrm{~min}$ before placement in the home cage (negative punishment), while those making the correct choice were permitted to eat the food reward for $5 \mathrm{~s}$ before being removed from the platform (positive reinforcement). Mice were considered to reach criterion when they chose correctly at least $80 \%$ of the time for 3 consecutive days.

Cookie test. This test measured a mouse's ability to use its whiskers to discriminate between cookies of different shapes and was adapted from a similar test used for rats (Brecht et al., 1997). Flat, 1-mm-thick cookies were made from sugar, butter, flour $(1: 2: 6)$ and water. Target cookies were right triangles ( $6 \mathrm{~mm}$ side length); nontarget cookies were squares ( $6 \mathrm{~mm}$ side length). Single mice were placed on a $10 \mathrm{~cm}^{2}$ platform with a $3 \mathrm{~cm}^{2}$ side platform upon which the cookies were placed. Mice were familiarized with the cookies in their home cage for several days before testing. For training, mice were presented with single target cookies on the platform in the light, followed by one target and one nontarget cookie. Mice were only allowed to explore the cookies with their whiskers; grabbing a cookie with the paws was considered a choice. Correct choices were positively reinforced with a small milk reward followed by removal from the platform, while incorrect choices were positively punished by tail pinch. After the mice reliably recognized and ate the target cookies (typically 2-3 d), first two ( 1 target and 1 nontarget) and then three ( 1 target and 2 nontarget) cookies were placed in a line on the platform under infrared illumination and each session was videotaped. Ten trials were conducted per day and scored offline. Mice were considered to reach criterion when they chose correctly at least $70 \%$ of the time for 3 consecutive days.

\section{Immunostaining}

Foot pads and shaved, depilated whisker pads were dissected from adult mice, fixed in ice-cold $4 \%$ paraformaldehyde, equilibrated in sucrose, embedded, and cryosectioned $(25 \mu \mathrm{m})$. Tissue was stained with rat antikeratin 8 (TROMA1, 1:20 dilution; Developmental Studies Hybridoma Bank), secondary antibodies (1:500 dilution; Jackson ImmunoResearch), and DAPI.

\section{Cell counts}

Whole feet were fixed as above and serially cryosectioned $(200 \mu \mathrm{m})$, then immunostained with TROMA1 and DAPI. All Merkel cells in the glabrous foot surfaces were counted.

\section{Statistical analysis}

Two-way ANOVA and/or $t$ tests were used, depending on the experimental paradigm. Unless otherwise noted, data were pooled within genotype with male and female mice treated equivalently. All data are reported as mean \pm SEM.

\section{Results}

Krt14; Atoh $1^{C K O}$ mice completely lack Merkel cells in the whiskers, body skin, and feet (Fig. 1) (Morrison et al., 2009). To determine the impact of this loss on animal behavior, we tested several measures of sensory function in adult $\mathrm{Krt14}$; Atoh1 ${ }^{\mathrm{CKO}}$ and control mice.

\section{Tactile sensation in the feet}

Several tests of motor function in rodents require intact tactile sensation. On dowel and wire hang testing, no differences were seen between Krt14; Atoh1 ${ }^{\text {CKO }}(n=12)$ and control $(n=24)$ mice on time to fall $(120 \pm 0$ vs $119 \pm 1 \mathrm{~s}, p=0.33$, and $100 \pm 11$ vs $96 \pm 8 \mathrm{~s}, p=0.77$, respectively; $t$ test) or number of side touches $(2.08 \pm 0.59$ vs $2.21 \pm 0.31, p=0.84$ and $2.67 \pm 0.38$ vs $2.83 \pm 0.38, p=0.78$, respectively; $t$ test). We therefore moved to the more challenging rotarod test. No differences were seen between $K r t 14$; Atoh $1^{C K O}$ and control mice in time to fall on any day (day 1: $83 \pm 13$ vs $70 \pm 5 \mathrm{~s}, p=0.26$, $t$ test; day $2: 104 \pm 12$ vs $94 \pm$ $6 \mathrm{~s}, p=0.40$; day $3: 128 \pm 16$ vs $109 \pm 8 \mathrm{~s}, p=0.24$; day $4: 138 \pm$ 17 vs $121 \pm 9 \mathrm{~s}, p=0.33)$ and mice of both genotypes improved with training (ANOVA: $p=0.046$ for Krt14; Atoh $1^{\text {CKO }}$ mice and $p=6.07 \times 10^{-6}$ for control mice). These data demonstrate that 
Krt14; Atoh $1^{\text {CKO }}$ mice learn and perform normally on motor tasks that presumably require intact tactile sensation in the feet, suggesting that Merkel cells are not required for these tasks.

To further test specific proposed functions of Merkel cells, we modified and implemented a simple texture discrimination task (Wetzel et al., 2007) that measured preference for a rough versus smooth floor surface. We validated the test on two separate cohorts of male and female wild-type C57BL/6J mice; male mice had no preference, while female mice had a strong preference for the rough surface (Table 1). Therefore, we tested only female Krt14; Atoh $1^{\text {CKO }}$ and control mice. As shown in Table 1, female Krt14; Atoh $1^{C K O}$ mice showed no preference for the rough surface. These data suggest that they have lost the ability to detect texture differences, and thus lost the wild-type female mouse preference for rough over smooth surfaces.

We reasoned that wild-type female mice might be more sensitive to textures because of increased numbers or density of Merkel cells in the glabrous surfaces of their paws. Keratin 8 immunostaining on tissue sections from the left hindpaw of C57BL/6J mice used for sensory testing demonstrated no differences in the total numbers of Merkel cells in the glabrous foot surfaces $(547 \pm 32 \mathrm{vs}$ $584 \pm 66, p=0.62, t$ test $)$ of female $(n=$ $5)$ and male $(n=5)$ mice, respectively. Furthermore, plantar surface areas of female $\left(0.459 \pm 0.020 \mathrm{~cm}^{2}\right)$ versus male $\left(0.460 \pm 0.017 \mathrm{~cm}^{2}\right)$ mice were equivalent $(p=0.83, t$ test $)$. Therefore differences in Merkel cell number or density cannot explain the observed gender-related texture preferences.

Finally, we hypothesized that reproductive cycle stage might affect female texture preference. When the second cohort of C57BL/6J female mice was tested, two were in diestrus, five were in estrus, two were in proestrus and one was in metestrus. Thus, differences in the menstrual cycle do not explain the texture preference of female mice.

\section{Tactile sensation in the whiskers}

The whiskers are the most sensitive and specialized tactile organs in rodents, who use them to determine spatial position and physical characteristics of nearby objects (Diamond et al., 2008). Rodent whisker follicles contain large numbers of Merkel cells and Merkel cell/neurite complexes, which are located at the midshaft and opening of each follicle (Fig. $1 A, A^{\prime}$ ) (Fundin et al., 1997; Cronk et al., 2002). We therefore reasoned that whisker function might be profoundly affected by loss of Merkel cells.

We used the whisker brush test as a general measure of whisker function. Both Krt14; Atoh1 ${ }^{C K O}(n=11)$ and control $(n=24)$ mice demonstrated immediate reactions to whisker contact, and no qualitative differences in their responses were detected.

We next used the modified gap test to determine the ability of Krt14; Atoh $1^{\text {CKO }}$ mice to discriminate between rough and smooth
Table 1. Control male and $K r t 14 ; A t o h 1^{C K O}$ female mice show no texture preference in open field testing

\begin{tabular}{|c|c|c|c|c|c|}
\hline Mice & $n$ & $\begin{array}{l}\text { Percentage of } \\
\text { mice with rough } \\
\text { preference }\end{array}$ & $\begin{array}{l}\text { Time on rough } \\
\text { surface (in } \mathrm{S}, \\
\text { mean } \pm \text { SEM) }\end{array}$ & $\begin{array}{l}\text { Time on smooth } \\
\text { surface (in s, } \\
\text { mean } \pm \text { SEM) }\end{array}$ & $\begin{array}{l}t \text { test } p \text { value } \\
\text { (rough vs smooth) }\end{array}$ \\
\hline $\begin{array}{l}\text { (57BL/6J male } \\
\text { cohort } 1\end{array}$ & 12 & $50 \%$ & $866 \pm 69$ & $934 \pm 69$ & 0.49 \\
\hline $\begin{array}{c}\text { C57BL/6J male } \\
\text { cohort } 2\end{array}$ & 10 & $40 \%$ & $966 \pm 74$ & $834 \pm 74$ & 0.13 \\
\hline $\begin{array}{l}\text { Krt14; Atoh1 }{ }^{\text {CKO }} \\
\text { females }\end{array}$ & 16 & $50 \%$ & $918 \pm 89$ & $881 \pm 89$ & 0.84 \\
\hline $\begin{array}{l}\text { C57BL/6J female } \\
\text { cohort } 1\end{array}$ & 12 & $92 \%$ & $1197 \pm 83$ & $603 \pm 83$ & $4.4 \times 10^{-5}$ \\
\hline $\begin{array}{l}\text { C57BL/6J female } \\
\text { cohort } 2\end{array}$ & 10 & $100 \%$ & $1049 \pm 35$ & $751 \pm 35$ & $1.2 \times 10^{-5}$ \\
\hline $\begin{array}{l}\text { Control littermate } \\
\text { females }\end{array}$ & 10 & $100 \%$ & $1436 \pm 79$ & $364 \pm 79$ & $7.9 \times 10^{-5}$ \\
\hline
\end{tabular}

textures using only their whiskers. Based on our open field testing, we examined a small cohort of female $\operatorname{Krt14}$; Atoh ${ }^{C K O}(n=$ $3)$ and control $(n=8)$ mice on this task. All mice used a similar strategy consisting of leaning over the edge of the home platform, extending the body, and contacting the target platform with the whiskers. Mice often did this several times before crossing, and they never attempted to cross unless they could first contact the 
target platform. No differences in whisking strategy were observed between $\mathrm{Krt14}$; Atoh1 ${ }^{\mathrm{CKO}}$ and control mice. All of the Krt14; Atoh $1^{\text {CKO }}$ mice (100\%) and three of the eight control mice (37.5\%) reliably ( $>80 \%$ of the time on 3 consecutive days) chose the correct platform after several days ( $16 \pm 4$ vs $19 \pm 3.5, p=$ 0.43 , respectively; $t$ test) of training; we therefore did not expand the number of mice tested. Thus, Krt14; Atoh $1^{\text {CKO }}$ mice were able to learn this task at the same speed and with the same accuracy as control mice, suggesting that texture discrimination using their whiskers was not compromised.

Finally, we tested the ability of a small cohort of Krt14; Atoh $^{\text {CKO }}(n=5)$ and control $(n=5)$ mice to distinguish shapes using their whiskers (see Materials and Methods, above). Three of five (60\%) Krt14; Atoh1 ${ }^{C K O}$ and three of five (60\%) control mice met criteria in a similar average number of days $(24.3 \pm 5.2$ vs $19.3 \pm 2.3, p=0.43, t$ test); again, we did not test more animals because the Krt14; Atoh $1{ }^{C K O}$ mice were able to perform the task. These data suggest that loss of Merkel cells does not overtly impair mice from distinguishing shapes using their whiskers.

\section{Discussion}

Our data provide the first direct evidence that Merkel cells, and presumably the SAI afferents that innervate them, are required for certain texture discrimination tasks. Interestingly, this requirement is not universal, as mice lacking Merkel cells cannot distinguish between markedly different textures using their feet but can distinguish textures using their whiskers. One possibility is that Merkel cell loss in the paw abolishes preference for but might not affect detection of rough versus smooth textures per se. Further experiments using special training paradigms are needed to test this possibility. Another explanation is that mechanosensitive functions of SAI afferents in the whiskers do not require Merkel cells, representing a departure from the situation in the body skin where Merkel cells are required for SAI responses (Maricich et al., 2009). This explanation seems unlikely as it invokes different mechanoreceptor mechanisms for the same apparatus in different parts of the body. Instead, we hypothesize that the difference between the foot pads and whiskers of Krt14; Atoh $1^{\text {CKO }}$ mice in our texture discrimination assays results from the number of mechanoreceptor subtypes found in these two locations. Only two low-threshold mechanoreceptors (Merkel cell/neurite complexes and Meissner corpuscles) are present in mouse foot pads; thus, loss of one system could profoundly affect cutaneous mechanosensation. In contrast, multiple $\mathrm{A} \beta, \mathrm{A} \delta$, and $\mathrm{C}$-fiber mechanoreceptors heavily innervate the whiskers (Rice et al., 1997), so overlapping function of some or all of these mechanosensitive systems could substitute for Merkel cell/neurite complex function in the whiskers of Krt14; Atoh1 ${ }^{C K O}$ mice. This hypothesis is supported by psychophysical studies in humans demonstrating that while stimulation of individual afferent subclasses evokes different primary sensations (Ochoa and Torebjörk, 1983), typical cutaneous stimuli rarely activate only one type of mechanoreceptor. Instead, routine handling of objects simultaneously excites multiple afferent classes (Jenmalm et al., 2003), and this sensory information subsequently converges onto many of the same neurons of the primary somatosensory cortex (Pei et al., 2009). A directly relevant observation is that textures can be detected by humans either by direct contact of the skin with a surface (presumably mediated by Merkel cell/neurite complexes) or through a rigid probe held in the hand and dragged along that surface (presumably mediated by Meissner and/or Pacinian corpuscles) (Yoshioka et al., 2007). These data suggest that information from different afferents can be interpreted similarly by higher order centers. Another possibility for our study is that our genetic approach, which prevented production of Merkel cells altogether, provided an opportunity for adjacent somatosensory systems in the whiskers to anatomically and/or functionally substitute for disrupted Merkel cell/neurite complexes during development. The effects of early ablation versus deletion of Merkel cells in adulthood are an area of research we are actively exploring.

Behavioral evaluation of tactile responsiveness beyond mechanical nociception in freely behaving rodents has been limited and focused primarily on the whiskers (Carvell and Simons, 1990; Brecht et al., 1997; Cybulska-Klosowicz and Kossut, 2001; von Heimendahl et al., 2007). However, preference of wild-type mice for textured over nontextured surfaces has been reported previously (Wetzel et al., 2007). In that study, deletion of stomatin-like protein 3 (SLP3), a mammalian mec-2 homolog implicated in mechanotransduction, abolished electrophysiological responses to mechanical stimuli in 35\% of cutaneous mechanoreceptors including $\mathrm{A} \beta$ and $\mathrm{A} \delta$ afferents. Paw-mediated discrimination between textured and nontextured surfaces was also impaired in SLP3 $3^{-/-}$mice (Wetzel et al., 2007). Our data are consistent with these findings and suggest the interpretation that $S L P 3^{-/-}$mice exhibit impaired texture discrimination secondary to compromised Merkel cell/neurite complex function. Interestingly, SLP3 ${ }^{-1-}$ mice, like Krt14; Atoh ${ }^{\text {CKO }}$ mice, also had normal performance on rotarod testing despite their more profound deficit in cutaneous mechanoreceptor responsiveness. This, coupled with normal performance of Krt14; Atoh ${ }^{C K O}$ mice on dowel and wire hang testing, suggests that most motor testing is insensitive to manipulations of the cutaneous sensory system. Further studies will be necessary to determine whether mice with other cutaneous mechanoreceptor deficits show impairments on these tests.

Another interesting finding of our study is that wild-type mice exhibit sexually dimorphic texture preferences, with females preferring rough-textured surfaces and males having no preference between rough and smooth surfaces. Female-male differences have been observed in behavioral tests of motor activity (Frantz and Van Hartesveldt, 1999; Palanza et al., 2001; Schindler et al., 2002), fear and anxiety (Imhof et al., 1993), pain tolerance (Kepler et al., 1991; Aloisi et al., 1994; Terner et al., 2003), and measures of learning (Mishima et al., 1986). To our knowledge, our study is the first to report this finding for texture preference. We also show that this effect is not mediated by Merkel cell number or density in the paw, suggesting that higher-order centers within the nervous system mediate the preference. We hypothesize that female preference for rough surfaces might stem from sex differences in different brain regions or from differences in sex hormone levels between females and males (Ngun et al., 2011). How a proclivity for textured surfaces might benefit female mice is unclear. Further studies are needed to determine when during postnatal development this preference first arises and whether it is innate or learned.

\section{References}

Aloisi AM, Albonetti ME, Carli G (1994) Sex differences in the behavioural response to persistent pain in rats. Neurosci Lett 179:79-82.

Ben-Arie N, Bellen HJ, Armstrong DL, McCall AE, Gordadze PR, Guo Q, Matzuk MM, Zoghbi HY (1997) Math1 is essential for genesis of cerebellar granule neurons. Nature 390:169-172.

Brecht M, Preilowski B, Merzenich MM (1997) Functional architecture of the mystacial vibrissae. Behav Brain Res 84:81-97.

Carvell GE, Simons DJ (1990) Biometric analyses of vibrissal tactile discrimination in the rat. J Neurosci 10:2638-2648. 
Cronk KM, Wilkinson GA, Grimes R, Wheeler EF, Jhaveri S, Fundin BT, Silos-Santiago I, Tessarollo L, Reichardt LF, Rice FL (2002) Diverse dependencies of developing Merkel innervation on the trkA and both fulllength and truncated isoforms of trkC. Development 129:3739-3750.

Cybulska-Klosowicz A, Kossut M (2001) Mice can learn roughness discrimination with vibrissae in a jump stand apparatus. Acta Neurobiol Exp (Wars) 61:73-76.

Dassule HR, Lewis P, Bei M, Maas R, McMahon AP (2000) Sonic hedgehog regulates growth and morphogenesis of the tooth. Development 127:4775-4785.

Diamond ME, von Heimendahl M, Knutsen PM, Kleinfeld D, Ahissar E (2008) 'Where' and 'what' in the whisker sensorimotor system. Nat Rev Neurosci 9:601-612.

Frantz KJ, Van Hartesveldt C (1999) The locomotor effects of quinpirole in rats depend on age and gender. Pharmacol Biochem Behav 64:821-826.

Fundin BT, Silos-Santiago I, Ernfors P, Fagan AM, Aldskogius H, DeChiara TM, Phillips HS, Barbacid M, Yancopoulos GD, Rice FL (1997) Differential dependency of cutaneous mechanoreceptors on neurotrophins, trk receptors, and P75 LNGFR. Dev Biol 190:94-116.

Halata Z, Grim M, Bauman KI (2003) Friedrich Sigmund Merkel and his "Merkel cell", morphology, development, and physiology: review and new results. Anat Rec A Discov Mol Cell Evol Biol 271:225-239.

Iggo A, Muir AR (1969) The structure and function of a slowly adapting touch corpuscle in hairy skin. J Physiol 200:763-796.

Imhof JT, Coelho ZM, Schmitt ML, Morato GS, Carobrez AP (1993) Influence of gender and age on performance of rats in the elevated plus maze apparatus. Behav Brain Res 56:177-180.

Jenmalm P, Birznieks I, Goodwin AW, Johansson RS (2003) Influence of object shape on responses of human tactile afferents under conditions characteristic of manipulation. Eur J Neurosci 18:164-176.

Johnson KO (2001) The roles and functions of cutaneous mechanoreceptors. Curr Opin Neurobiol 11:455-461.

Johnson KO, Lamb GD (1981) Neural mechanisms of spatial tactile discrimination: neural patterns evoked by braille-like dot patterns in the monkey. J Physiol 310:117-144.

Johnson KO, Yoshioka T, Vega-Bermudez F (2000) Tactile functions of mechanoreceptive afferents innervating the hand. J Clin Neurophysiol 17:539-558.

Kelly EJ, Terenghi G, Hazari A, Wiberg M (2005) Nerve fibre and sensory end organ density in the epidermis and papillary dermis of the human hand. Br J Plast Surg 58:774-779.

Kepler KL, Standifer KM, Paul D, Kest B, Pasternak GW, Bodnar RJ (1991) Gender effects and central opioid analgesia. Pain 45:87-94.

Liu Q, Vrontou S, Rice FL, Zylka MJ, Dong X, Anderson DJ (2007) Molecular genetic visualization of a rare subset of unmyelinated sensory neurons that may detect gentle touch. Nat Neurosci 10:946-948.

Maricich SM, Wellnitz SA, Nelson AM, Lesniak DR, Gerling GJ, Lumpkin EA,
Zoghbi HY (2009) Merkel cells are essential for light-touch responses. Science 324:1580-1582.

Merkel FS (1875) Tastzellen and Tastkoerperchen bei den Hausthieren und beim Menschen. Arch Mikrosc Anat 11:636-652.

Mishima N, Higashitani F, Teraoka K, Yoshioka R (1986) Sex differences in appetitive learning of mice. Physiol Behav 37:263-268.

Morrison KM, Miesegaes GR, Lumpkin EA, Maricich SM (2009) Mammalian Merkel cells are descended from the epidermal lineage. Dev Biol 336:76-83.

Ngun TC, Ghahramani N, Sánchez FJ, Bocklandt S, Vilain E (2011) The genetics of sex differences in brain and behavior. Front Neuroendocrinol 32:227-246

Ochoa J, Torebjörk E (1983) Sensations evoked by intraneural microstimulation of single mechanoreceptor units innervating the human hand. J Physiol 342:633-654.

Palanza P, Morley-Fletcher S, Laviola G (2001) Novelty seeking in periadolescent mice: sex differences and influence of intrauterine position. Physiol Behav 72:255-262.

Paré M, Elde R, Mazurkiewicz JE, Smith AM, Rice FL (2001) The Meissner corpuscle revised: a multiafferented mechanoreceptor with nociceptor immunochemical properties. J Neurosci 21:7236-7246.

Pei YC, Denchev PV, Hsiao SS, Craig JC, Bensmaia SJ (2009) Convergence of submodality-specific input onto neurons in primary somatosensory cortex. J Neurophysiol 102:1843-1853.

Rice FL, Fundin BT, Arvidsson J, Aldskogius H, Johansson O (1997) Comprehensive immunofluorescence and lectin binding analysis of vibrissal follicle sinus complex innervation in the mystacial pad of the rat. J Comp Neurol 385:149-184.

Schindler CW, Bross JG, Thorndike EB (2002) Gender differences in the behavioral effects of methamphetamine. Eur J Pharmacol 442:231-235.

Shroyer NF, Helmrath MA, Wang VY, Antalffy B, Henning SJ, Zoghbi HY (2007) Intestine-specific ablation of mouse atonal homolog 1 (Math1) reveals a role in cellular homeostasis. Gastroenterology 132:2478-2488.

Terner JM, Lomas LM, Smith ES, Barrett AC, Picker MJ (2003) Pharmacogenetic analysis of sex differences in opioid antinociception in rats. Pain 106:381-391.

von Heimendahl M, Itskov PM, Arabzadeh E, Diamond ME (2007) Neuronal activity in rat barrel cortex underlying texture discrimination. PLoS Biol 5:e305.

Wetzel C, Hu J, Riethmacher D, Benckendorff A, Harder L, Eilers A, Moshourab R, Kozlenkov A, Labuz D, Caspani O, Erdmann B, Machelska H, Heppenstall PA, Lewin GR (2007) A stomatin-domain protein essential for touch sensation in the mouse. Nature 445:206-209.

Yoshioka T, Bensmaïa SJ, Craig JC, Hsiao SS (2007) Texture perception through direct and indirect touch: an analysis of perceptual space for tactile textures in two modes of exploration. Somatosens Mot Res $24: 53-70$ 